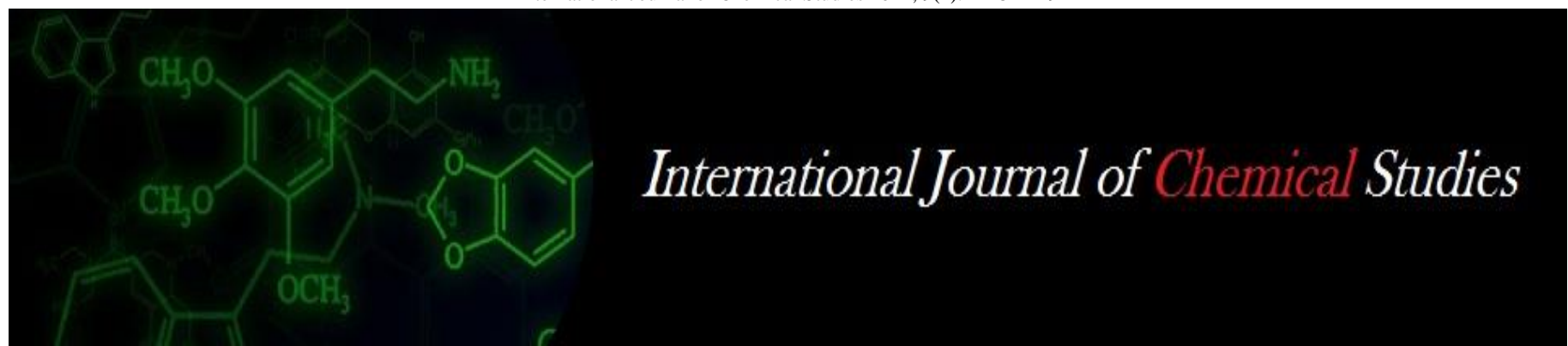

P-ISSN: 2349-8528

E-ISSN: 2321-4902

www.chemijournal.com

IJCS 2021; 9(1): 1125-1129

(C) 2021 IJCS

Received: 08-11-2020

Accepted: 17-12-2020

Goraviyala Jahnavi

Ambedanbhai

Department of Horticulture,

Madhav University, Pindwara,

Rajasthan, India

Anshuman Singh

Department of Horticulture,

ANDUAT, Kumarganj

Ayodhya, Uttar Pradesh, India

Corresponding Author:

Goraviyala Jahnavi

Ambedanbhai

Department of Horticulture,

Madhav University, Pindwara,

Rajasthan, India

\section{Studies on the changes in physico-chemical properties during storage and economics of date palm (Phoenix dactylifera) ready-to-serve (RTS) per bottle}

\author{
Goraviyala Jahnavi Ambedanbhai and Anshuman Singh
}

DOI: https://doi.org/10.22271/chemi.2021.v9.i1p.11374

\begin{abstract}
The present investigation entitled "Studies on the changes in physico-chemical properties during storage and economics of date palm (Phoenix dactylifera) Ready-To-Serve (RTS) per bottle" was carried out at Faculty of Agricultural Science, Madhav University, Pindwara, Rajasthan and the Post-Harvest laboratory, Department of Horticulture, College of Agriculture, Junagadh Agriculture University, Junagadh (Gujarat) during the year 2018-19. The Main objectives of the present investigation date palm RTS to evaluate the sensory parameters and their stability at room temperature, storage and the economics of various treatments for date palm RTS beverages was also worked out. Among the treatments two pulp concentration $20 \%$ \& $25 \%$ pulp and 3 levels of TSS i.e. (16\%, $17 \%$ and $18 \%$ of RTS) were used for preparation of the RTS. The $\%$ TSS values recorded for date palm RTS increases with the increase in sugar content and storage period the highest value of $\%$ TSS was registered with treatment $6^{\text {th }}(25 \%$ pulp $+18 \%$ TSS $+0.3 \%$ acidity of RTS $)$. The higher value of $\%$ acidity was recorded with the treatment $6^{\text {th }}(25 \%$ pulp $+18 \%$ TSS of RTS $)(0.91 \%)$ at final stage of observation. At initial stage the maximum (393.91) TSS/Acid ratio was recorded with the (60) TSS/Acid ratio was recorded with the treatment $3^{\text {rd }}$ and $6^{\text {th }}(20 \%$ pulp $+18 \%$ TSS of RTS and $25 \%$ pulp $+18 \%$ TSS of RTS respectively). The value of $\mathrm{pH}$ at initial stage was recorded minimum in the treatment $2^{\text {nd }}(6.82)$ and the maximum value was recorded in treatment $5^{\text {th }}(6.84)$. Economics of the treatment was calculated the minimum cost i.e. Rupees 24.7 per bottle was recorded with the treatment $1^{\text {st. }}$ Whereas, the maximum cost was recorded with the treatment $6^{\text {th }}$.
\end{abstract}

Keywords: Date palm, ready to serve (RTS)

\section{Introduction}

1.1 Date palm and date fruit

Date palm (Phoenix dactylifera) is an important fruit which belongs to Arecaceae (Palme) family. It is monocotyledonous plant, dioecious in nature and acquires more than $30 \mathrm{ft}$ height. Date is originated from Iraq. Date fruit can be preserved, stored, and carried easily over long distances, especially in dry and arid climates. It is a particularly important product in arid and semi-arid regions of the world.

\subsection{Date Palm area and production in India}

Date production is a world agricultural industry producing about 5.4 million metric tonnes of fruit. The cultivation of date palm is wide spread in the Arabic countries, Africa and Israel. In India, Date is grown commercially in Gujarat Kutch district costal belt from Anjar to Mandavi and Ganganagar, Bikaner, Jodhpur, Jaisalmer districts of Rajasthan.

\subsection{Nutritional value of dates}

Carbohydrates are the major chemical constituents of dates, including mainly reducing sugars such as glucose and fructose, and also non-reducing sugars such as sucrose, and small amounts of polysaccharides such as cellulose and starch. Date Palm Fruit Contains Water 5 to 20 (\%), Suger 44 to $88(\%)$, Protein 1 to $7(\%)$, Fat 0.1 to $0.5(\%)$, Pectin 1 to $4(\%)$, crude fiber 3 to 18(\%) and Polyphenol $3(\%)$. 


\subsection{Date fruit development stages}

There are five stages of date development: Hebabouk (Loss of unfertilized carpels), kirmi (Hard, mature and green fruit), doka (khalal) (Hard, yellow/pink/red, TSS 30-45\%, moisture 50-65\%), rutab (Softening starts, moisture 30-45\%, weight loss) and, pind (Full ripe).

\subsection{Date fruit value added products}

Many products of Dates including RTS (ready to serve), chhuharah, chutney, date syrup, jam, alcohol, animal feed, date powder, different types of bread, marmalade, sweet candy, chocolate, date paste, and others, can be obtained from different processing products. However in recent time table dates demand is decreasing and usage of processed product of date has also increased mostly in urban area. To utilize the produce at the time of glut and to save it from spoilage, the development of low cost processing technology of date palm fresh fruit is required.

\section{Materials and Methods}

The Experiment was carried out in Department of Horticulture, Faculty of Agricultural Science, Madhav University, Pindawara, Rajasthan and Post-Harvest laboratory Department of Horticulture Agricultural Collage of Junagadh Agricultural University, Junagadh, Gujarat.

\section{Experimental Details}

Processed product: Ready To Serve (RTS) of date palm, Variety: Barhi, Treatment: Factor (A) 2 levels of fruit pulp ratio and Factor (B) 3 levels of TSS, Total number of treatment: 6, No. of replication: 4 and Design: Factorial CRD.

\subsection{Procedure of RTS preparation}

The extracted pulp was used for the preparation of blended RTS. The required quantity of pulp was mixed with measured quality of water and then grinded sugar, citric acid, potassium metabisulphate were also added to it. In all the six treatments similar method was used (as per ratio of pulp, quantity of sugar \& citric acid potassium metabisulphate.) The pulp and sugar was mixed thoroughly and heated up to $65^{\circ} \mathrm{C}$ to dissolve it properly. It was then filtered with muslin cloth to remove impurities \& extract juice.

\section{Results and Discussion}

\subsection{Effect of storage period and blend ratio on the $\mathrm{pH}$ of date palm RTS}

The $\mathrm{pH}$ values of date palm RTS as affected by various treatments was also estimated at various intervals of storage and presented in Table 1 . The acidity is directly correlated with the $\mathrm{pH}$ values of a particular product.

A perusal of the data given in Table 1 leads to the conclusion that storage period was significantly effective in reducing the $\mathrm{pH}$ values of date palm RTS with various treatments the $\mathrm{pH}$ values decreased continuous with the increased storage period.

It was clear from the data that the quantity of sugar and pulp added to RTS beverage significantly influenced the $\mathrm{pH}$ values of the beverage. It was obvious from the data that higher value was recorded with date palm pulp at treatment $4^{\text {th }}, 25$ per cent pulp +16 per cent TSS +0.3 per cent acidity of RTS. The increasing quantity of sugar in RTS reduced the $\mathrm{pH}$ values and this trend was observed.

Table 1: Effect of storage period and blend ratio on the $\mathrm{pH}$ of date palm RTS

\begin{tabular}{|c|c|c|c|c|c|c|c|c|}
\hline $\begin{array}{c}\text { Treatments Pulp (\%)+ Acidity } \\
(\%)+\text { TSS of RTS (\%) }\end{array}$ & $\begin{array}{c}\mathbf{0} \\
\text { days }\end{array}$ & $\begin{array}{c}\mathbf{1 5} \\
\text { days }\end{array}$ & $\begin{array}{c}\mathbf{3 0} \\
\text { days }\end{array}$ & $\begin{array}{c}\mathbf{4 5} \\
\text { days }\end{array}$ & $\begin{array}{c}\mathbf{6 0} \\
\text { days }\end{array}$ & $\begin{array}{c}\mathbf{7 5} \\
\text { days }\end{array}$ & $\begin{array}{c}\mathbf{9 0} \\
\text { days }\end{array}$ & $\begin{array}{c}\text { MEAN of } \\
\text { Treatments }\end{array}$ \\
\hline $\mathrm{T} 1(20+0.3+16)$ & 6.83 & 6.75 & 5.55 & 5.00 & 4.68 & 4.52 & 4.52 & 5.40 \\
\hline $\mathrm{T} 2(20+0.3+17)$ & 6.82 & 6.76 & 6.54 & 5.30 & 4.59 & 4.56 & 4.56 & 5.59 \\
\hline $\mathrm{T} 3(20+0.3+18)$ & 6.83 & 6.76 & 6.53 & 5.25 & 4.80 & 4.74 & 4.74 & 5.66 \\
\hline $\mathrm{T} 4(25+0.3+16)$ & 6.83 & 6.77 & 6.54 & 5.30 & 5.0 & 4.75 & 4.75 & 5.70 \\
\hline $\mathrm{T} 5(25+0.3+17)$ & 6.84 & 6.26 & 5.53 & 5.21 & 5.0 & 4.74 & 4.74 & 5.47 \\
\hline T6 (25+0.3+18) & 6.73 & 6.77 & 6.54 & 5.23 & 4.85 & 4.66 & 4.66 & 5.63 \\
\hline MEAN & 6.81 & 6.67 & 6.20 & 5.21 & 4.82 & 4.66 & 4.66 & \\
\hline S.Em \pm & 1.65 & 1.61 & 1.51 & 1.26 & 1.17 & 1.13 & 1.13 & \\
\hline CD & 2.21 & 2.15 & 2.02 & 1.68 & 1.56 & 1.51 & 1.51 & \\
\hline
\end{tabular}

\subsection{Effect of storage period and blend ratio on the Acidity of date palm RTS}

The acidity of the fruits or processed product is very important as regard the quality is concerned. Because the TSS, acid blend in fruits is the major factor responsible for the taste. The data recorded on per cent acidity of date palm RTS as affected by the treatments were recorded from 0 to 90 days of storage at 15 days interval as presented in Table 2.
The data given in Table 2 show that the per cent acidity of date palm RTS increased continuously and significant difference in all the treatment with the progress in storage period up to 90 days. At 0 days of storage the maximum per cent acidity in date palm RTS was recorded 0.3 per cent of RTS. However, similar trend in increase of acidity content was recorded in all the storage period at 15 days interval up to 90 days i.e. termination of the experimentation.

Table 2: Effect of storage period and blend ratio on the Acidity of date palm RTS

\begin{tabular}{|c|c|c|c|c|c|c|c|c|}
\hline $\begin{array}{c}\text { Treatments Pulp (\%)+ Acidity } \\
(\%)+\text { TSS of RTS(\%) }\end{array}$ & $\begin{array}{c}\mathbf{0} \\
\text { days }\end{array}$ & $\begin{array}{c}\mathbf{1 5} \\
\text { days }\end{array}$ & $\begin{array}{c}\mathbf{3 0} \\
\text { days }\end{array}$ & $\begin{array}{c}\mathbf{4 5} \\
\text { days }\end{array}$ & $\begin{array}{c}\mathbf{6 0} \\
\text { days }\end{array}$ & $\begin{array}{c}\mathbf{7 5} \\
\text { days }\end{array}$ & $\begin{array}{c}\mathbf{9 0} \\
\text { days }\end{array}$ & $\begin{array}{c}\text { Mean of } \\
\text { Treatments }\end{array}$ \\
\hline T1 (20+0.3+16) & 0.3 & 0.40 & 0.50 & 0.51 & 0.51 & 0.64 & 0.74 & 0.44 \\
\hline T2 (20+0.3+17) & 0.3 & 0.50 & 0.60 & 0.60 & 0.64 & 0.76 & 0.84 & 0.52 \\
\hline T3 (20+0.3+18) & 0.3 & 0.45 & 0.5 & 0.44 & 0.75 & 0.89 & 0.90 & 0.60 \\
\hline T4 (25+0.3+16) & 0.3 & 0.48 & 0.5 & 0.51 & 0.70 & 0.76 & 0.89 & 0.59 \\
\hline T5 (25+0.3+17) & 0.3 & 0.35 & 0.5 & 0.58 & 0.67 & 0.76 & 0.80 & 0.63 \\
\hline T6 (25+0.3+18) & 0.3 & 0.42 & 0.56 & 0.64 & 0.70 & 0.89 & 0.91 & 0.63 \\
\hline MEAN & 0.3 & 0.43 & 0.52 & 0.54 & 0.66 & 0.78 & 0.84 & \\
\hline S.Em \pm & 0.07 & 0.10 & 0.12 & 0.13 & 0.16 & 0.19 & 0.20 & \\
\hline CD & 0.09 & 0.13 & 0.16 & 0.17 & 0.21 & 0.25 & 0.26 &
\end{tabular}




\subsection{Effect of storage period and blend ratio on the TSS of date palm RTS}

The data on Total Soluble Solids content of date palm RTS as influenced by various treatments at different stages of storage period at 15 days interval are presented in Table 3 .

A perusal of the data given in Table 3 revealed that an appreciables increases in total soluble solids per cent was observed with the increase in storage period up to 90 days of storage. This change in total soluble solids content was observed in almost all the treatments.
The pulp content of RTS also influences the total soluble solids percentage. The higher total soluble solids content was recorded in the RTS having more pulp per cent ( 25 per cent pulp per liter of RTS). However, lower values were recorded with 20 per cent pulp per liter of RTS.

The sugar content significantly affected the values of total soluble solids percentage and it was in proportionate with the quantity of sugar added in RTS. The maximum total soluble solid was recorded $(20.15)$ with the treatment $6^{\text {th }}$ i.e. 25 per cent pulp per liter +18 per cent TSS of RTS.

Table 3: Effect of storage period and blend ratio on the TSS of date palm RTS

\begin{tabular}{|c|c|c|c|c|c|c|c|c|}
\hline $\begin{array}{c}\text { Treatments Pulp (\%) + Acidity } \\
(\%)+\text { TSS of RTS (\%) }\end{array}$ & $\begin{array}{c}\mathbf{0} \\
\text { days }\end{array}$ & $\begin{array}{c}\mathbf{1 5} \\
\text { days }\end{array}$ & $\begin{array}{c}\mathbf{3 0} \\
\text { days }\end{array}$ & $\begin{array}{c}\mathbf{4 5} \\
\text { days }\end{array}$ & $\begin{array}{c}\mathbf{6 0} \\
\text { days }\end{array}$ & $\begin{array}{c}\mathbf{7 5} \\
\text { days }\end{array}$ & $\begin{array}{c}\mathbf{9 0} \\
\text { days }\end{array}$ & $\begin{array}{c}\text { Mean of } \\
\text { Treatments }\end{array}$ \\
\hline T1 (20+ 0.3+16) & 16 & 16.30 & 16.45 & 17.3 & 18.5 & 18.5 & 18.5 & 17.36 \\
\hline T2 (20+0.3+17) & 17 & 17.8 & 17.9 & 18.2 & 18.45 & 18.53 & 18.7 & 18.08 \\
\hline T3 (20+0.3+18) & 18 & 18.5 & 18.6 & 19.2 & 19.2 & 19.3 & 19.3 & 18.87 \\
\hline T4 (25+0.3+16) & 16 & 17.2 & 17.2 & 17.5 & 17.5 & 17.6 & 17.8 & 17.25 \\
\hline T5 (25+0.3+17) & 17 & 17.62 & 17.85 & 17.9 & 18.22 & 18.4 & 18.5 & 17.92 \\
\hline T6 (25+ 0.3+18) & 18 & 19.4 & 19.4 & 19.7 & 19.7 & 20 & 20.15 & 19.47 \\
\hline MEAN & 17 & 17.82 & 17.9 & 18.46 & 18.48 & 18.63 & 18.82 & \\
\hline S.Em \pm & 4.14 & 4.33 & 4.36 & 4.49 & 4.52 & 4.53 & 4.58 & \\
\hline CD & 5.54 & 5.80 & 5.84 & 6.01 & 6.05 & 6.06 & 6.13 & \\
\hline
\end{tabular}

\subsection{Effect of storage period and blend ratio on the TSS/acid of date palm RTS}

The blend of sugars with acid evaluates the taste of any preserved fruit product. Under this study also the observations were recorded on the effect of storage period and blend ratio on the TSS/acid ratio of RTS and presented in Table 4.

Data pertaining to TSS/acid ratio as influenced by various treatments clearly showed that with the advancement of storage period, TSS/acid ratio decreased. Higher TSS/acid ratio was noticed with the treatment 1 st i.e. 20 per cent pulp + 16 per cent TSS liter of RTS after 90 days of storage. Whereas, at 0 days the value was (53.3) with this recipe. However, reduction in TSS/acid ratio was observed continuously in decreasing trend at every stage of observation at 15 days interval during storage.

Table 4: Effect of storage period and blend ratio on the TSS/Acid of date palm RTS

\begin{tabular}{|c|c|c|c|c|c|c|c|c|}
\hline $\begin{array}{c}\text { Treatments Pulp (\%)+ Acidity } \\
(\%)+\text { TSS of RTS (\%) }\end{array}$ & $\begin{array}{c}\mathbf{0} \\
\text { days }\end{array}$ & $\begin{array}{c}\mathbf{1 5} \\
\text { days }\end{array}$ & $\begin{array}{c}\mathbf{3 0} \\
\text { days }\end{array}$ & $\begin{array}{c}\mathbf{4 5} \\
\text { days }\end{array}$ & $\begin{array}{c}\mathbf{6 0} \\
\text { days }\end{array}$ & $\begin{array}{c}\mathbf{7 5} \\
\text { days }\end{array}$ & $\begin{array}{c}\mathbf{9 0} \\
\text { days }\end{array}$ & $\begin{array}{c}\text { Mean of } \\
\text { Treatments }\end{array}$ \\
\hline T1 (20+ 0.3+16) & 53.3 & 40.75 & 32.9 & 36.6 & 35 & 28.12 & 25 & 35.95 \\
\hline T2 (20+0.3+17) & 56.6 & 35.6 & 29.83 & 30.3 & 28.82 & 24.38 & 22.26 & 32.54 \\
\hline T3 (20+ 0.3+18) & 60 & 41.11 & 37.2 & 43.63 & 25.6 & 21.68 & 21.44 & 35.80 \\
\hline T4 (25+0.3+16) & 53.3 & 35.83 & 34.4 & 34.31 & 25 & 23.15 & 20 & 32.28 \\
\hline T5 (25+ 0.3+17) & 56.6 & 50.34 & 35.7 & 30.86 & 27.19 & 24.21 & 23.12 & 35.43 \\
\hline T6 (25+ 0.3+18) & 60 & 46.19 & 34.64 & 30.78 & 28.14 & 22.47 & 22.38 & 34.94 \\
\hline MEAN & 56.6 & 41.63 & 34.11 & 34.41 & 28.29 & 24 & 22.36 & \\
\hline S.Em \pm & 13.79 & 10.21 & 8.31 & 8.45 & 6.59 & 5.86 & 5.45 & \\
\hline CD & 18.47 & 13.67 & 11.13 & 11.31 & 8.82 & 7.84 & 7.30 & \\
\hline
\end{tabular}

\subsection{Economics of the treatments}

The economics of various treatments was worked out as higher money values and lesser cost of production or desirable traits for getting higher net returns. The data presenting to economics of different treatments influenced by various recipes are presented in Table 5.

A perusal of a data presented in Table 5 showed that the various treatments for the preparation of date palm RTS influenced the production cost in both the pulp concentration.
It is also revealed from the data that the highest $\mathrm{B}: \mathrm{C}$ ratio of 1.02:1 was recorded with the treatment 1 st and minimum $\mathrm{B}: \mathrm{C}$ ratio was recorded with the treatment $6^{\text {th }}(25$ per cent pulp + 18 per cent TSS of RTS) followed by treatment $5^{\text {th }}$ ( 25 per cent pulp +17 per cent TSS of RTS). The variation in production cost of RTS was due to difference in quantity of pulp and sugar used per liter of RTS. The data in Table has been presented for $200 \mathrm{ml}$ or per bottle of prepared RTS.

Table 5: Economics of treatment of $200 \mathrm{ml}$ or per bottle of prepared RTS

\begin{tabular}{|c|c|c|c|c|c|c|c|}
\hline $\begin{array}{c}\text { Treatments Pulp }(\%)+\text { Acidity }(\%)+ \\
\text { TSS of RTS }(\%)\end{array}$ & $\begin{array}{l}\text { Coast of fruit } \\
\text { pulp (Rs.) }\end{array}$ & $\begin{array}{c}\text { Coast of } \\
\text { Sugar (Rs.) }\end{array}$ & $\begin{array}{l}\text { Processing } \\
\text { coast (Rs.) }\end{array}$ & \begin{tabular}{|c|}
$\begin{array}{c}\text { Total Coast } \\
(\text { Rs. })\end{array}$ \\
\end{tabular} & $\begin{array}{c}\text { Assumed Gross } \\
\text { return (Rs.) } \\
\end{array}$ & $\begin{array}{l}\text { Net return } \\
(\text { Rs. })\end{array}$ & B:C Ratio \\
\hline T1 $(20+0.3+16)$ & 10.4 & 4.3 & 10 & 24.7 & 50 & 25.3 & $1.02: 1$ \\
\hline $\mathrm{T} 2(20+0.3+17)$ & 10.4 & 5.1 & 10 & 25.5 & 50 & 24.5 & 0.96:1 \\
\hline T3 $(20+0.3+18)$ & 10.4 & 5.3 & 10 & 25.7 & 50 & 24.3 & 0.94:1 \\
\hline $\mathrm{T} 4(25+0.3+16)$ & 13 & 4.3 & 10 & 27.3 & 50 & 22.7 & $0.83: 1$ \\
\hline T5 $(25+0.3+17)$ & 13 & 5.1 & 10 & 28.1 & 50 & 21.9 & $0.77: 1$ \\
\hline T6 $(25+0.3+18)$ & 13 & 5.3 & 10 & 28.3 & 50 & 21.7 & $0.76: 1$ \\
\hline
\end{tabular}




\section{$4.6 \mathrm{pH}$}

The $\mathrm{pH}$ value of a product plays an important role in the preservation of pulp. Lowering of $\mathrm{pH}$ value is the result of increased acidity. The low $\mathrm{pH}$ inhibits the activity of microorganism specially the Bacteria.

The data presented in Table revealed that an overall $\mathrm{pH}$ value during the study period less was than 7.0 i.e., acidic. However, the $\mathrm{pH}$ value recorded at initial period of storage $(0$ days) was higher in all the recipes and the maximum (6.84) was recorded with RTS of $5^{\text {th }}$ treatment $(25$ per cent +17 per cent TSS +0.3 per cent acidity of the RTS). It also revealed that $\mathrm{pH}$ value increased with the increase in ratio of pulp and also with the higher concentration of sugar. Moreover, the $\mathrm{pH}$ value also reduced as the storage period increased in all the recipes. It was higher with 4.74 treatment $4^{\text {th }}$ ( 25 per cent pulp +16 per cent TSS +0.3 per cent acidity of the RTS) and lower with 4.52 treatment $1^{\text {st }}$ (20 per cent pulp +16 per cent TSS +0.3 per cent acidity of the RTS). These results supported by the results obtained by Kalra and Revanthi (1983) ${ }^{[1]}$ reported that slightly decreased in $\mathrm{pH}$ during 60 days storage of guava pulp. Sethi and Jindal (1997) [3] reported that the acidity increased with corresponding decreases in $\mathrm{pH}$. This might be due to the formation of organic acid by ascorbic acid degradation. Shriwastava (1998) ${ }^{[4]}$ noticed that the $\mathrm{pH}$ decreased with increase storage period.

\subsection{Acidity}

The result recorded for the $\%$ acidity value, revealed that the order of $\%$ acidity increased in accordance with the increasing storage period gradually up to 90 days of storage. Similar trend was observed with the increasing pulp with the RTS. Higher, values were recorded for $\%$ acidity with $25 \%$ pulp content as compared to $20 \%$ pulp content RTS. The quantity of sugar added to RTS also affected the \% acidity and the highest $(\%)$ acidity $(0.91)$ was recorded with the treatment $6^{\text {th }}$ $(25$ per cent +18 per cent TSS +0.3 per cent acidity of the RTS). The increase in acidity in RTS during 90 days of storage might be due to formation of organic acid by ascorbic acid degradation as well as progressive decrease in pectin content. Lowest value was observed $0.74 \%$ with treatment $1^{\text {st }}$ $(20$ percent pulp +16 per cent TSS +0.3 per cent acidity of the RTS). With bael-guava blends beverage. These findings are in conformation with the findings of Choudhary, et al., (2006) ${ }^{[8]}$ who observe that there was gradual increase in acidity value with an increase in the storage period in guava RTS. Mishra et al., (2013) ${ }^{[13]}$ indicated that there was an increases in acidity per cent with the increase storage period in bael candy. Similar results were reported by Punam, et al., (2009) ${ }^{[11]}$ who observe that the increase acidity per cent with increase storage period in the bael-mango blended RTS.

\subsection{TSS (\%)}

The result obtained from the present investigation revealed that the higher concentration of date palm pulp increased the TSS per cent of date palm RTS and this effect was observed up to 90 days of storage. Similar, effect of sugar contents with various treatment ( 1 to 6) with RTS also persisted for 90 days of storage. However, the increasing trend in TSS content was recorded in all the recipes up to 90 days of storage. The value of TSS was higher 20 with treatment $6^{\text {th }}(25$ percent pulp +18 per cent TSS +0.3 per cent acidity of the RTS). The lowest value was recorded with treatment $1^{\text {st }}(20$ per cent pulp +16 per cent TSS +0.3 per cent acidity of the RTS). It clearly indicates that lower the sugar and pulp content lower is the TSS and higher the sugar and pulp content higher is the TSS.
This also indicates that the TSS value increases with increase in storage period. Similar results were reported by Baramanray, et al., (1995) ${ }^{[2]}$ and Deka et al., (2005) ${ }^{[6]}$ also reported that the TSS of guava nector and TSS of mangopineapple spiced beverages increased during storage period. Similar results were reported by Jakhar \& Pathak (2012) ${ }^{[12]}$ in blended RTS of ber and jamun.

\subsection{TSS/Acid Ratio}

The result presented in Table indicated that TSS/Acid ratio was influenced by various treatments and it was noticed that reduction in TSS/Acid ratio was continuous at every stage of observation up to 90 days storage and this reduction was highly significant. Further, it was observed that the TSS/Acid ratio was also influence by the various recipes used for the preparation of the RTS. The maximum value (25) was registered with the recipe $1^{\text {st }}(20 \%$ pulp $+16 \%$ TSS of RTS $)$ and it was because of the increasing quantity of sugar in all the treatments. This might be due to increased quantity of sugar which is directly correlated with the TSS/Acid ratio of date palm.

RTS as influenced by quantity of sugar added. These findings are in conformation as reported by Singh, et al., (2005) ${ }^{[7]}$ who reported that there was decrease in quality character of mango + bael beverage with the advance storage period but it remained above the acceptable rating even after 6 months of storage. Similar findings have been reported by other workers Pandey (2004) ${ }^{[5]}$ and Sharma, et al., (2008) ${ }^{[9]}$.

\subsection{Economics}

The data presented in Table regarding economics of various treatments influenced by blend ratio indicate that the gross return was common for the product i.e. date palm RTS beverages and assumed value of Rupees 50 per bottle was estimated with all the treatments. However, clear difference in production cost was recorded with the different treatments and this difference was due to the quantity of pulp and sugar added with different recipes. The maximum production cost i.e. Rupees 28.3 was recorded with the treatment 6 th whereas, the minimum cost was observed with treatment $1^{\text {st }}$. As regard the $\mathrm{B}: \mathrm{C}$ ratio is concerned the maximum $\mathrm{B}: \mathrm{C}$ ratio was recorded with the treatment 1 st and the minimum $\mathrm{B}: \mathrm{C}$ ratio $(0.76: 1)$ was observed with the treatment $6^{\text {th }}$. Similarly, Baghel (2008) ${ }^{[10]}$ also reported good B:C ratio for mixed fruit jelly.

\section{Summary and Conclusion}

The $\mathrm{pH}$ value for date palm RTS was also influenced by the various treatment, pulp and TSS content. However, the value of $\mathrm{pH}$ at initial stage was the minimum in the treatment $2^{\text {nd }}$ (6.82) and was maximum in treatment $5^{\text {th }}(6.84)$. It was significantly decreased with the increasing storage period.

The higher value of acidity (\%) was recorded with the treatment $6^{\text {th }}(25 \%$ pulp $+18 \%$ TSS of RTS $)(0.91 \%)$ at final stage of observation. The acidity of RTS increased in all the treatments and it was increased with the increase in storage period. TSS also affected the \% acidity and it was noted higher with the increase in TSS.

The \% TSS values for date palm RTS increased with the increase in storage period the highest value of $\%$ TSS was recorded with treatment $6^{\text {th }}(25 \%$ pulp $+18 \%$ TSS $+0.3 \%$ acidity of RTS) followed by treatment $3^{\text {th }}(20 \%$ pulp $+18 \%$ TSS $+0.3 \%$ of RTS) indicting that the TSS value also affect by pulp ratio. 
The TSS/Acid ratio of mango RTS was also influenced by various recipes. It was decreased with the increasing storage period. At initial stage the maximum (60) TSS/Acid ratio was recorded with the treatment $3^{\text {rd }}$ and $6^{\text {th }}(20 \%$ pulp $+18 \%$ TSS of RTS and $25 \%$ pulp $+18 \%$ TSS of RTS respectively). Whereas, minimum (53.30) TSS/Acid ratio was recorded with the treatment $1^{\text {st }}$ and $4^{\text {th }}(20 \%$ pulp $+16 \%$ TSS of RTS and $25 \%$ pulp $+16 \%$ TSS of RTS respectively). The RTS prepared with treatment $3^{\text {rd }}(20 \%$ pulp $+18 \%$ TSS of RTS $)$ recorded higher values of TSS/Acid ratio at every stage of observation during storage period up to 45 days. After 45 days TSS/Acid ratio recorded higher for treatment $1^{\text {st }}(20 \%$ pulp $+16 \%$ TSS)

The economics of the treatments was calculated for $200 \mathrm{ml}$ of RTS (per bottle). The minimum cost i.e. Rupees 24.7 per bottle was recorded with the treatment 1 st, whereas, the maximum cost was recorded with the treatment 6th i.e. Rupees 28.3 per bottle. The cost difference was due to the cost of different fruits pulp ratio and the quantity of sugar added. The maximum (1.02:1) $\mathrm{B}: \mathrm{C}$ ratio was observed in the treatment $1^{\text {st }}$ whereas, the minimum $(0.76: 1) \mathrm{B}: \mathrm{C}$ ratio was recorded with the treatment 6 th. However, the $\mathrm{B}: \mathrm{C}$ ratio of all the treatment indicates that the product is marketable which confirms the commercial utility of the treatment.

On the basis of present investigation it is concluded that the quality and the overall acceptability was better with $20 \%$ pulp $+16 \%$ TSS $+0.3 \%$ acidity of RTS with the cultivar Barhi. It is also concluded from the studies that the date palm RTS prepared from this low cost technology can be stored for longer period with better acceptability, good quality, and marketability without any microbial growth at room temperature.

\section{References}

1. Kalra SK, Revanthi G. Chemical and microbial evaluation stored guava pulp in P.V.C. containers. Journal Food Science Technology 1983;20(3):118-120.

2. Baramanray A, Gupta AP, Dhawan SS. Evaluation of guava (Psidium guajava L.) hybrids for making nectar. Haryana Journal Horticulture Science 1995;24(2):102109.

3. Sethi V, Jindal PC. Evaluation of new grape hybrid juice for processing. Haryana Journal of Horticulture Science 1997;26(3-4):208.

4. Shrivastava JS. Comparative study of RTS drinks prepared from Dasheheri and Banganpalli mangoes. Indian Food Packer 1998;52(2):38-42.

5. Pandey AK. Study about the storage storability of guava beverage. Progressive Horticulture 2004;36(1):142-145.

6. Deka BC, Sethi V, Saikia A. Changes in quality of mango-pineapple spiced beverage during storage. Indian Journal of Horticulture 2005;62(1):65-68.

7. Singh S, Godara RK, Saini RS, Sharma JR. Standardization of processing technology for bael/blended bael (Aegle marmelos) Ready-To-Serve beverages. Haryana Journal Horticulture Science 2005;34(3-4):263-265.

8. Choudhary ML, Dikshit SN, Sharma HG. Studies on preparation and biochemical changes in guava Ready-ToServe beverage during storage. Indian Journal of Arid Horticulture 2006;1:78-79.

9. Sharma I, Kaul RK, Bhat A. Effect of different treatment combinations of guava and papaya on quality and storability of ready-to-serve beverages. Journal of Research SKUASTJ 2008;7(1):1-8.
10. Baghel AS. Evaluation of various recipes of preparation of wood apple (Feronia limonia L.) and guava (Psidium guajava L.) mixed jelly and its quality. M.Sc. (Ag.) Thesis, Deptt. Of Horticulture, JNKVV Jabalpur 2008.

11. Punam Gehlot R, Singh R, Siddiqui S. Studies on physico-chemical composition of fresh bael and mango fruits. Haryana Journal of Horticultural science 2009;38(1\&2):66-67.

12. Jakhar MS, Pathak S. Studies on the preparation and storage stability of blended Ready-to-serve from ber and jamun pulp. Plant Archives 2012;12(1):533-536.

13. Mishra DK, Saroj PL, Pathak S. Effect of packaging containers on storage stability of bael (Aegle marmelos) candy under ambient conditions. Progressive Horticulture 2013;45(1):122-125. 